\title{
The Message/Moral through Photography - TV and a Child
}

\author{
Sibila Petenji Arbutina and Jelena Kovačević Vorgučin \\ The Higher Technical School of Professional Education, \\ Novi Sad, Serbia, Academy of Art, Novi Sad, Serbia
}

\section{sibila.petenji.arbutina@gmail.com jelka.photo@gmail.com}

\begin{abstract}
This paper sets out to analyze how art conveys a message and an idea by means of visual expression. Using the visual language within the MIND TV project, we refer to the effects of TV on children development. The main aim of this project is to direct the society towards more sensible use of television and to raise media literacy in order to achieve better socialization and healthier life for children/society of the postmodern age. Through the MIND TV project, it is explained how the visual expression might become the means of raising awareness and opening a dialogue. The factors influencing the picture context are shown. A particular emphasis is placed on the explanation of the circumstances which led to the decline in quality of the cultural development of the country we come from, which justifies the need for educating the society in the field of art and media.
\end{abstract}

Key words: culture, children and television, art, photograph, presentation of art, unconventional expression

\section{Introduction}

Visual expression is present in every segment of society and is one of the most powerful means of passing on information. For this reason, this paper makes use of the photographic media as means of conveying symbolic and educational messages aimed at development of culture and media literacy in the territory of Serbia. Using visual expression in the form of a photograph, we indirectly point to the problem of media illiteracy of the society we come from, in which the negligence of art and culture can be felt due to having been culturally closed for several decades as a consequence of various political crises.

We analyze the factors affecting the poor quality of culture and lack of media literacy on a global as well as on a local level - in the territory of Serbia, and the possibility for the adequate use of the medium of television for educational purposes.

Material published as part of this publication, either on-line or in print, is copyrighted by the Informing Science Institute. Permission to make digital or paper copy of part or all of these works for personal or classroom use is granted without fee provided that the copies are not made or distributed for profit or commercial advantage AND that copies 1) bear this notice in full and 2) give the full citation on the first page. It is permissible to abstract these works so long as credit is given. To copy in all other cases or to republish or to post on a server or to redistribute to lists requires specific permission and payment of a fee. Contact Publisher@InformingScience.org to request redistribution permission.
For the above-mentioned reasons, we deal with the analysis of the visual part of the project whose aim is to raise the awareness of the strong effect of television programme on children. Depending on its content, TV program might create good or bad personality attributes in children. 


\section{The Factors Affecting the Creation of Visual Expression/TV and a Child}

\section{Social and Cultural Needs in Turbulent Regions}

The institutions established by the society have a key role in the process of developing cultural needs, but a family or the social background have a significant impact on development and bringing up of an individual. The development and acknowledgement of cultural needs might be spontaneous or organized but this process is undoubtedly influenced by:

- Cultural atmosphere of the family life

- Local community and peer groups

- Institutional forms (1. Schools, 2. Libraries, archives etc. and 3. Museums, galleries, theatres, concert halls)

- The mass media: radio, cable and satellite TV, newspapers, Internet presentations, classic media (newspapers) digitized into online editions, digitized libraries, online entertainment, films, music and music videos. (Dragićević Šešić \& Dragojević, 2007).

However, if culture is marginalized due to volatile political and economic factors in one area, the development of cultural needs of an individual is also neglected, which eventually leads to a cultural crisis of a whole society. Turbulence in a society is the consequence of substantial economic changes such as: the end of industrial stage in development, severe economic crises brought about by financial breakdown of national economy, big natural disasters, wars, political changes - the setting up of a new political system, redefining of the national framework, ideological and social changes - the change of ethics, national identity and representation; nationalism, religious and ethnic intolerance (Dragićević Šešić\& Dragojević, 2005, p. 22).

Serbia is, beyond any doubt, a turbulent part of the world where all the above-mentioned factors can apply to. The fact that it was closed for several years led to a long period of stagnation, even alienation and regression in every aspect of work and life: economy, politics, science, the arts etc. Therefore, the issues of cultural democracy and quality of cultural life, as well as the quality and means of presenting culture, were left on the margins being no matter for debate due to such turbulent circumstances. As Golubović Z., a scientific adviser at the Institute for humanities and a professor of social and cultural anthropology at the University of Belgrade, has noted: "Culture in Serbia has been marginalized and it is at an extremely low level, which is evidenced by the fact that only a quarter of the citizens understands its meaning in everyday life." (Golubović, 2010, http://www.srbijanet.rs).

Turbulence in a society affects people's consciousness and the ways they accept information, which Z. Golubović has argued in her research in the field of anthropology: "A classification of the respondents can be made into the ones who know nothing about culture and who are mainly dedicated to the "bare living", the ones in the middle who are consumers of culture and who visit museums and theatres only when they have enough money, and a small number of the ones who form a group of the "conscious", who are critically and culturally orientated." (Golubović, 2010, p.27)

During the interview for the Blic, a daily newspaper, she added that "the culture is not comprehended as a way of living and that it is culture which gives us the direction and determines main values by which it will be developed "(Golubović, 2010, http://www.srbijanet.rs). 
These facts could, to a large extent, explain poorly developed critical thinking, lack of media literacy and cultural habits, which are considered virtually indispensable for the development of a personality that is able to contribute to the quality of society.

\section{Hyperproduction of Information}

There is a massive accumulation of the spectacle in the contemporary consumer society, which is brought about by the vast array of industrial products, their captivating advertisements and blissful shops. The rapid consumption of commodities that tempt a consumption-obsessed person into obtaining them, but which are nevertheless easily replaced by new ones, accounts for a neverending multiplication and accumulation of fake images, magic and satisfaction that the spectacle arouses.

The entire human life is turned into a game of special effects, flamboyant images, and intense feelings of pleasure. The media culture of television is omnipresent, thus greatly affecting our senses and the ways we comprehend the world. The power of these images is seemingly concealed, but in fact it is great and manipulative.

In everyday life, we are exposed to continual influence of images which reduce our perception to a mere reception of superficial impressions or information deprived of any meaning. The more information we are faced with, the less knowledge we have. With such a ratio, any effectiveness of communication is lost.

This leads to the "implosion" of all meanings, destruction of diversity and any known sense. The hyperproduction of information that is put together for its own sake and is aimed at itself creates the hyper-realty which the contemporary society considers as the only possible reality (Djordjevic J., 2009, p.238-239).

The modern age, supported by technical and technological development, has adhered to the belief that the information age broadens knowledge, develops communication and allows greater freedom. According to Baudrillard as Djordjevic explained "media representation of reality is reduced to a sheer 'inscenation' (mise en scène), 'anti-theatre', 'recycling' and simulacrum (the parallel world or the product which tends to 'present the reality as being even more realistic than it is'), by which the reality is denied, having become a misconception and a myth" (Djordjevic, 2009, p.239).

This can lead to the conclusion that absolute and massive exposure to the media (absolute reliance on the media) might make every information questionable in terms of its purpose because it seems that its aim is not to establish communication or gain more freedom, but to create a mere 'mise en scène'.

In addition, the inevitable contact with the images presented by the media, especially by television production of different representations of reality in the form of soap operas, news, reality shows and tabloid talk shows, which promote kitsch and pulp content as a common value system, as well as wars, scandals etc. enables the establishment of a fake relationship between those who are concerned for own lives and those who represent their lives (the media). Personal life is immersed into an artificial universe.

If such content becomes an integral part of everyday life, and such a threat is more than likely to occur in the turbulent parts of the world, there is an enormous danger of its influence on the development of society. Furthermore, being over-saturated with information might lead to absolute denial and rejection of all values. 


\section{Media (il)literacy and Culture}

Media literacy is the ability of an individual to reach, analyze and critically evaluate media content. This refers to all types of the media: television, film, radio and recorded music, the press, the Internet and all other digital communication technologies. On the individual level, the skills of media literacy refer to critical thinking, problem-solving, personal autonomy and communication skills. These skills are essential for the development of people, who would be eager to become active participants, on a social level. (Potter, 2011, p.33-34)

In Serbia, $98.2 \%$ of the population have a TV set, while $85 \%$ perceive TV as the main source of information and entertainment (Statistical Office of the Republic of Serbia 2012,

http://webrzs.stat.gov.rs). Hence, TV program is a powerful source of social literacy and information, as well as an emotional stimulus.

Media literacy and media culture are underdeveloped in the territory where we live, which has also been noted by Z. Golubović: "The impression of the majority of citizens is that the society moves backwards and that instead of transitional evolution, there is involution." [...] "In comparison to the culture and society of the 1960's and partly 1970's, when the culture was really appreciated and was omnipresent, and when the mass culture was far more substantial, the present-day mass culture is in fact a 'pink culture' (the culture based on low-budget shows promoting bad manners, tabloid talk shows, gossip, kitsch and pulp content) which represents frivolous entertainment." (Golubović, 2010, http://www.blic.rs).

The authors consider that providing a higher level of media literacy through education is necessary in Serbia in order to make an individual use the information received through the media in a sensible way. Thus, the impact on the whole society would be created with an aim to develop liberal thinking in an individual and establish higher social and cultural standards.

\section{The Impact of Television on Child Development}

\section{The Ambivalence of Thought}

There is no absolute definition according to which television is regarded as being good or bad. This depends on the program content, the time spent watching television, as well as on the social environment and circumstances in which one watches it.

The effects of television and the opinions on it are ambivalent. The one side of the argument considers these effects as positive, whereas the opponents deem them to be a necessary evil. On the one hand, there were great hopes and high expectations that television would enrich children's lives, stimulate their imagination and creativity, broaden their education and knowledge, encourage multicultural tolerance, bridge social gaps, facilitate development and democratization. On the other hand, there was a great fear that the power of television would stifle emotions, develop indifference to other people's suffering; that it would encourage destructive behavior and lead to degradation of moral values, suppression of local cultures, and social alienation.

Dr. Sovilj, a specialist at the Institute for Experimental Phonetics and Speech Pathology in Belgrade explains that "an average child of the pre-school age spends three hours a day watching $\mathrm{TV}$, and additional two or three hours playing video-games, which causes linguistic, psychomotor and locomotor impairment." (Sovilj, 2010, http://www.vrticiportal.com).

The research conducted by the Institute for Experimental Phonetics and Speech Pathology in Serbia proves that about $63 \%$ of the pre-school children (by the age of 7 ) have underdeveloped speech, whereas a high percentage of children do not speak at all by the age of four (2010, http://www.vrticiportal.com). 
Dr. Stanković, M.Sc., explains: "Violence, murders, pornography, racial, ethnic and gender intolerance, drug and alcohol abuse, are increasingly frequent topics of television programs. Since children are easy to impress and are proven to follow the simple principle of learning by example, they are likely to assume that what they see on television is typical, safe and acceptable."

(Stanković, 2012, http://www.stetoskop.info).

The same author also points out the potential health problems arising from excessive watching of $\mathrm{TV}$, such as: obesity, learning problems, insomnia, intense aggression, addiction, as well as the children's inability to make a difference between the fantasy world presented on TV and reality, which lead to children's passivity and social alienation.

Vujčić Popović, a pedagogue, explains that children by the third grade of elementary school, i.e. by the age of 9 , cannot understand with certainty the difference between "the reality" and "the virtual world" of the media. They do understand that TV shows are imaginary, but they believe that everything they have seen "could happen." (Vujčić Popović, 2010, http://roditeljstvo.com,).

Children are neither passive viewers nor the so-called "tabula rasa" where the television messages are written. On the contrary, children are active "consumers" of television. They respond to it, they think and feel, and they assign meanings to it (Lemish, .2005, p.12). Accordingly, it is clear that the question "How do children make use of television?" is as important as the question "How does television affect them?"

The usage of television in a society varies. The use of television which is not related to the content is fairly common because "it goes without saying that television is present everywhere" (Lemish, .2005, p.15). In such a case people do not pay attention to the content of the shows, not even to the textual content, since television is treated as a source of any sound or dynamic image. In fact, this the riskiest way of consumption for children as they are not controlled while watching $\mathrm{TV}$, and even if they do not watch it, they subconsciously absorb different images and sounds which can be of inappropriate content. Based on the authors research, $90 \% \mathrm{cca}$. of the parents (300 respondents) at least once a day use TV as "a nanny" so that they could do some household chores or have a rest etc.

On the other hand, there is a very rational way of "consuming" television. In such cases, television could have the role in providing social models of behavior to be copied and applied in problem-solving, or to encourage communication and provide solutions to the raised questions and doubts. Therefore, a limited and controlled amount of the time spent watching television is acceptable, even if it is used as a means of relaxation and temporary isolation from the everyday routine, when an individual escapes to their own world in order to relax. (e.g. a child who tries to relax after school watching a cartoon...) (Lemish, 2005, p.34-35).

Parents have to be aware of the fact that a child develops the habits concerning both watching and choosing TV programs by taking after the older family members. In the first place, the culture of watching television is developed at home, and we are of the opinion that parents/legal guardians should have the biggest influence on the way a child "consumes" television.

According to Lemish, D. "...there are at least three levels of parents' participation in the child's viewing of TV content." (Lemish, 2005, p.42) The first one is the level of "being aware of watching together", when the parent is present and acquainted with content of the program the child is viewing. They watch a program together, and thereby the parent provides a role model in terms of child's television viewing habits.

On the second level, parents supervise and limit the time spent on watching TV. They control the behavior of the child that is influenced by the program and its contents. This model is used either as a reward or as a punishment, and for this reason it is referred to as "the supervising level" or "restrictive mediation". 
On the third level, parents are actively involved in the viewing of programs together with their children. While watching, parents talk to their children, give explanations, assess values, incite emotions, process information, apply their knowledge and critically evaluate the content. Thus they contribute to the mediation between the children and the content. This is called "instructive mediation". (Lemish, 2005, p.43-44).

Visual information surrounds us in massive quantities almost every waking minute of every day. From television and internet ads, to billboards and magazines, visual information surrounds us. Some experts estimate that we are confronted with up to 5000 visual messages each day (2012, http://ocio.osu.edu).

The fact is that $70 \%$ of information is absorbed visually, by eyesight, and this should be considered when creating educational contents. That is a proper way of suggesting how a child might benefit from the program.

It has been proven that viewing TV together with children is a preferable activity. It is also noted that parents who have a negative attitude towards television are more frequently involved in various forms of mediation (Lemish, 2005, p.44-45), which is a perfectly reasonable approach, because in this way all the negative effects of lousy television content can be avoided.

These are some of the factors that motivated the authors to create a visual project within the educational campaign about the effects of TV on children, which is presented in the next section of the paper.

\section{Project - MIND TV}

In this section of the paper we analyze our own project - MIND TV exhibition. This project has been carried out upon the realization of the importance of parents' role in the child development in terms of the development of media literacy, cultural life and healthy personality. The idea for the project, whose aim is to raise the awareness of the ways in which television is used showing both positive and negative sides of its potential effects on children's development, has been shaped by the authors' personal experience, drawing especially on their parental experiences and other parents' opinions, as well as on the basis of the previous analyses.

The additional incentive for this project was the conversation between one of the authors with her daughter:

Daughter: Mum, can anybody ever enter the TV?

Mum: TV? No, they can't!

Daughter: How's that so! I saw in the cartoon we watched in the nursery that some man could! Mum: Of course that is possible when it is a part of someone's imagination, and they drew that in the cartoon.

The daughter, probably unhappy because it is possible in imagination only, says: That imagination is so boring!

As the problem has been identified in the author's personal parental experience, the aim is to convey the message, through the medium of a fine arts form - a photograph, to parents/legal guardians and make them become aware of the fact that the medium of television can exert powerful effects on children if its use is not controlled. The final outcome is related to its effects on the youngest population as the potential victims of the mass media. The project is aimed at parents, who should influence children in order to support their healthy development through conscious and purposeful use of the advantages of the post-modern age means of communication.

As a consequence of the rapid pace of life, parents spend increasingly less time with their children, devoting less time to discussion of problems or emotions. This relationship is often reduced 
to parents' teaching children only the basic principles of survival, which certainly leads to alienation. Therefore, if television is inevitably present in the everyday life, why wouldn't we share it with our children for a little while?

In this paper, we want to point out that art should not only be produced according to the concept formulated as art for art's sake, but that it should also open up discussion. This project sets out to show how much art serves the purpose of other fields of life. "Culture and art are not perceived as independent units, but demonstrate their relevance through effects they bring about within other fields of life and production segments, and thus they cannot be perceived as separate units." (Dragićević Šešić \& Dragojević , 2005, p.16 ). Every age makes new demands and sets new values which clearly reflect the way and needs of contemporary life. Photography, being the most realistic of all fine arts in terms of its approach to representation of reality, is recognized as the most suitable and fastest means for conveying the message. For this reason we have chosen it as our main means of expression. "Pictures have always been the surest way of conveying an idea, and next in order, words that call up pictures in memory." (Lippmann, 2007, p.154).

The theme of our photographs is the children, who indirectly should receive the message we want to convey. They are in the focus of the visual expression as intermediaries between the artist and the audience that are their parents in this case.

We took the photographs of children aged between two and ten while they were watching TV program. The parents had been given the explanation regarding taking photographs including the purpose of the photographs and the way of presenting them to the public. The parents had given their written consent by signing a legally recognized document.

Our presence with cameras, their clicking or flashes, did not, even for a moment, distract children from their virtual connection with TV. At that moment, the children do not notice any surrounding sounds or pictures apart from those coming from the TV set.

The en face close-up portrait puts a child's frozen facial expression into the focus of interest. This refers to the hypnotic effect that television program has on a child, as well as to a child's complete cutting off from reality. They are cramped, confined to a square shot. Within it, children do not have any space around themselves, which refers to the impossibility to move and think freely, and is to emphasize that they can easily become television or media slaves. By using a close-up and fitting the image into the set format, the attention is directed to the central part of the face, while the eyes come into the main focus. The look in children's eyes is not directed straight in the camera, i.e. the observer, but goes somewhere into the distance, above the camera. The children seem to be looking through us, which adds up to their isolation from the real world.

We used diffuse symmetrical side lighting set on the both sides of a child's face, which additionally confines the image to the set format. Using a particularly sharp photograph, which symbolizes and points to technological achievements, we intended to present the state of a complete cutting off from reality, as well as the absence of emotions towards the outer world. The focus of interest is on a child's expressionless face. The profound effects of the medium of television on children are symbolically presented by examining and documenting their faces devoid of any expression [see fig. 1.1.2.3.4.5.6.7.8.9.10.]. 
The Message/Moral through Photography

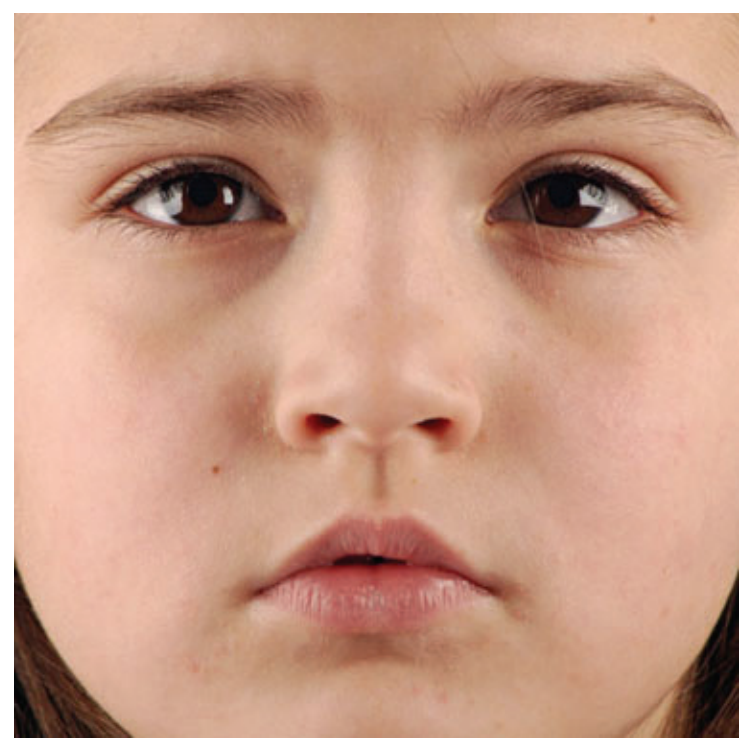

Fig.1.1.

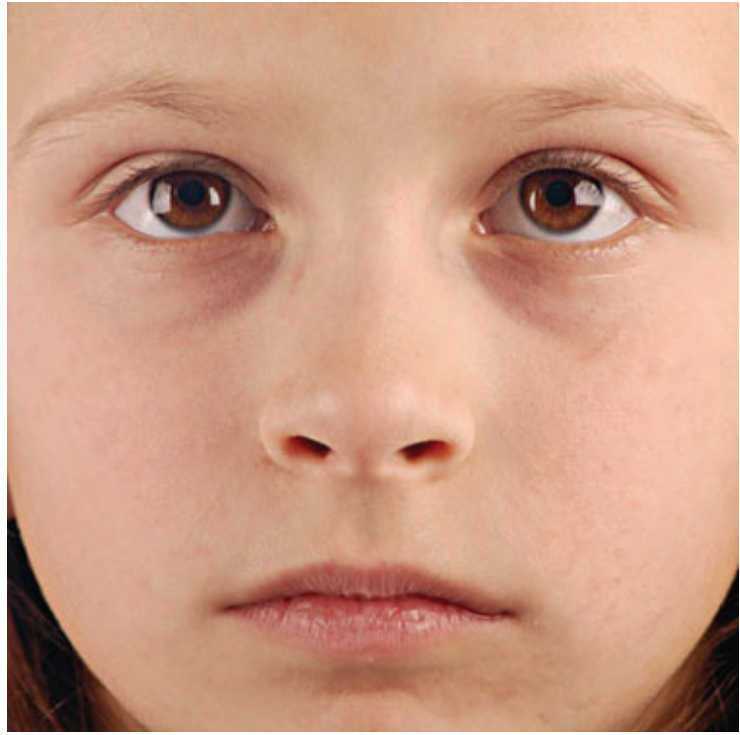

Fig.1.3.

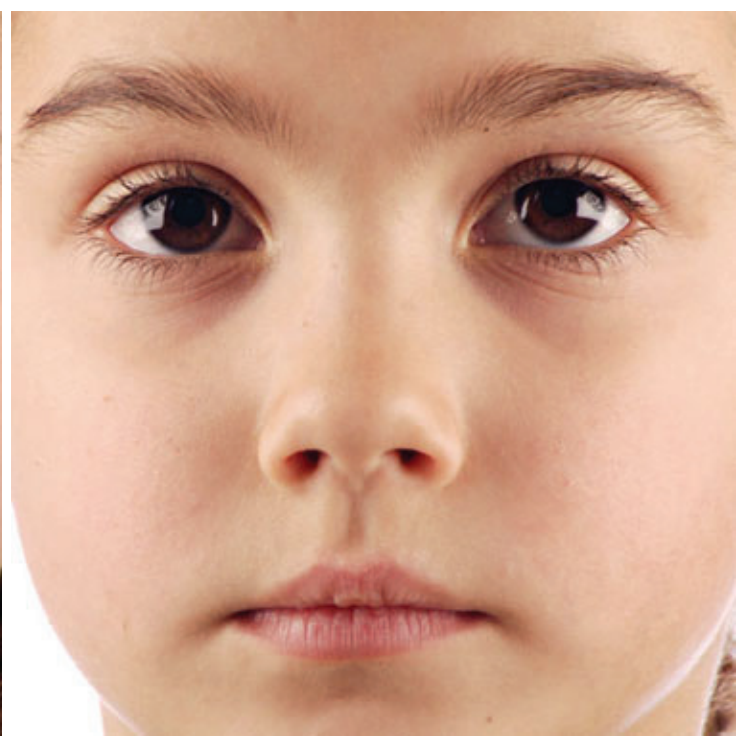

Fig.1.2.

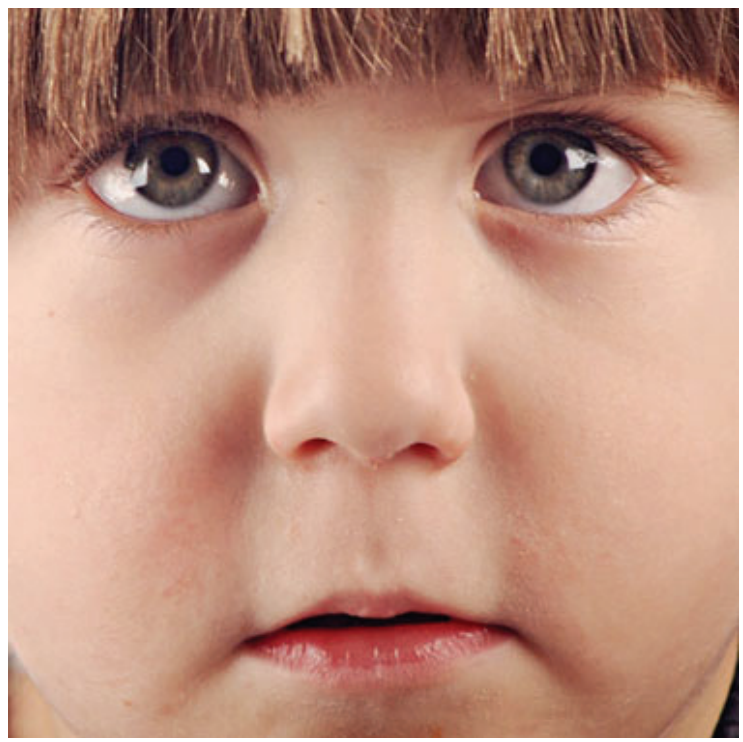

Fig.1.4. 
Petenji Arbutina \& Kovačević Vorgučin

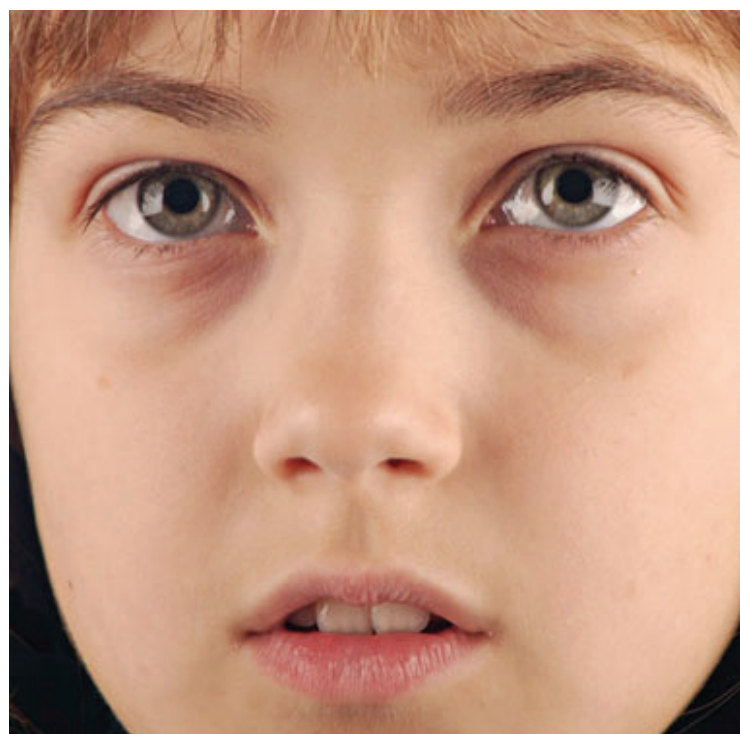

Fig.1.5.

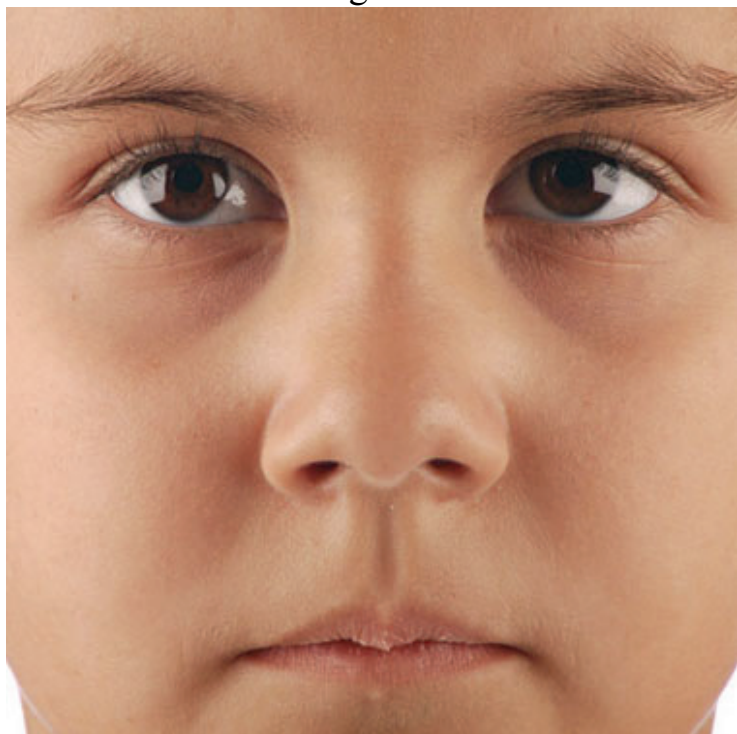

Fig.1.7.

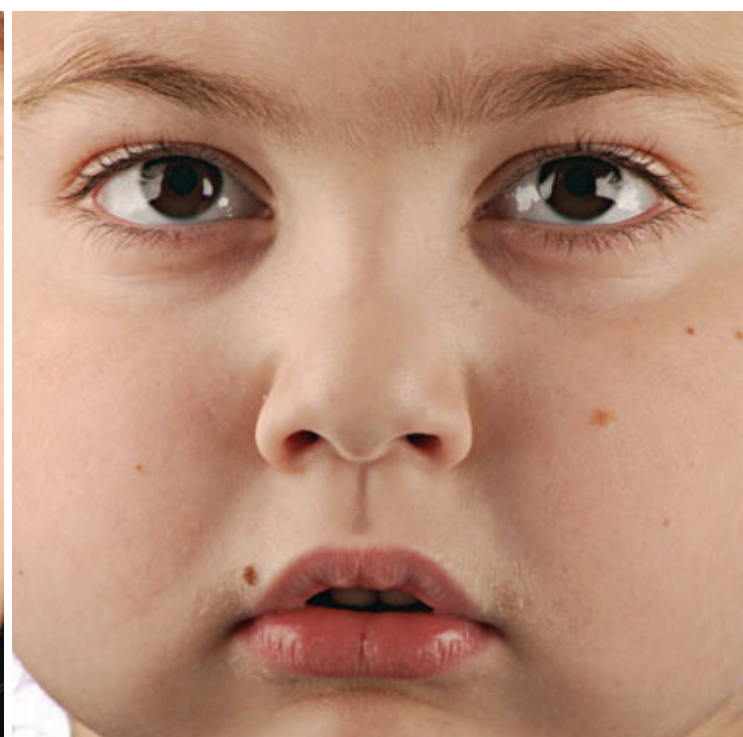

Fig.1.6.

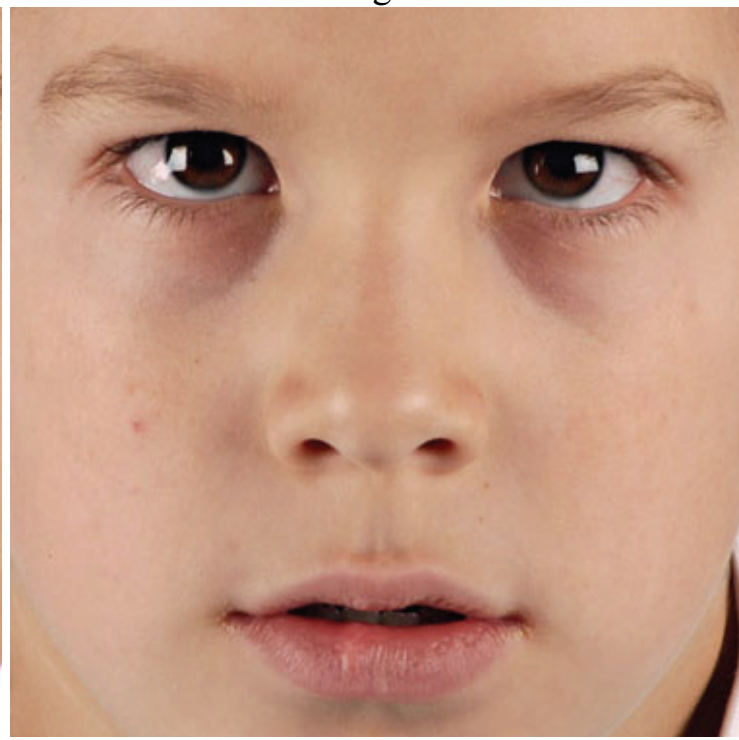

Fig.1.8. 


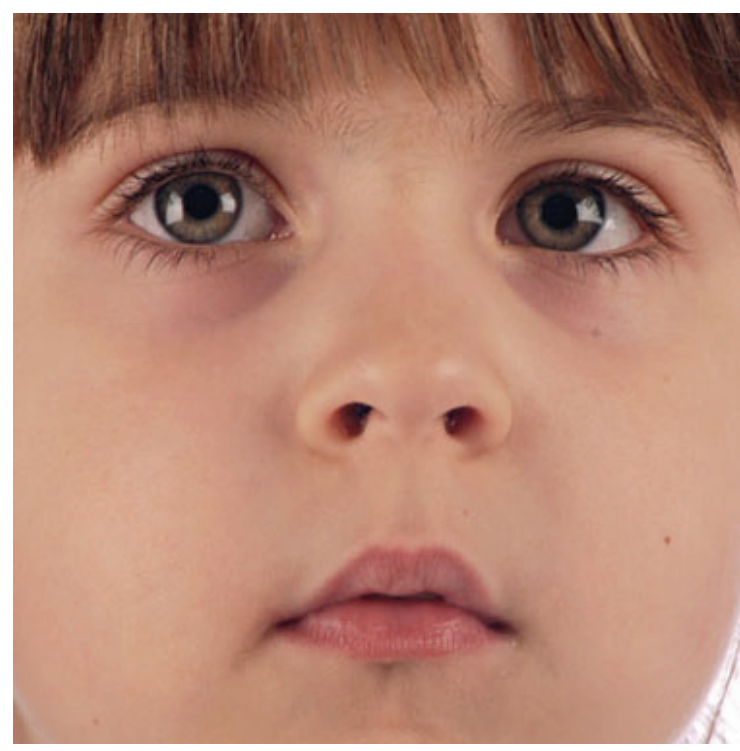

Fig.1.9.

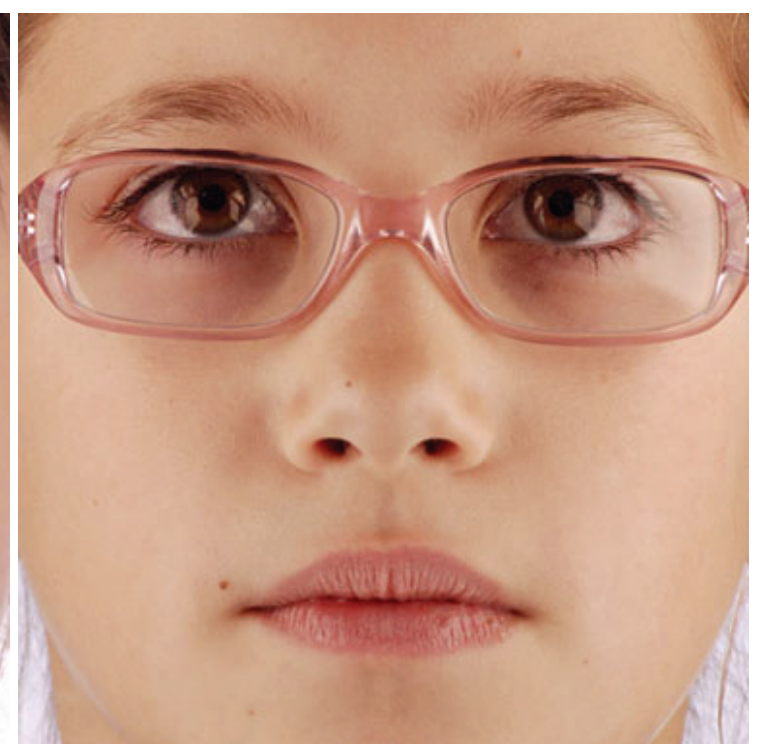

Fig.1.10.

Fig. 1. Expressionless faces (Personal work by authors, Novi Sad, Serbia)

\section{The Context of Children Representation}

In all fine arts, the representation of children has varied over the epochs. The context of the image always depends on numerous historical, economic, political and cultural factors. As Marilyn Brown, the professor of Art History, points out in her introduction, within art history "visual images of children have often been marginalized as a trivial, sentimental, or...feminized sub-genre; frequently they have been interpreted as timeless or universal" (Brown, 2002). The context of an image representing a child in the history of photography, which dates back to the second half of the $19^{\text {th }}$ century, has varied from the representation of an innocent, romantic ideal of childhood, i.e. Innocence childhood, originating in the art of romanticism, to today's modern representation of the attitude towards childhood (Higonnet, 1998). The authors claim that each piece of art has its historical base, and that it is impossible to exclude the spirit of the past or present from it or to leave out the social character.

The representation of children's faces in photography is usually related to mawkish feelings which overwhelm us when watching them. Every home has always paid special attention to family photo albums, whose role is to preserve the memories of those carefree days of childhood and growing up. The creating of home archives usually means keeping the images of smiling faces connected with the happiest events in life for which we have strong sentimental attachment.

In order to have the message seriously understood by the parents, the facial expressions of the children in the images are everything but mawkish or sentimental, which is contrary to what we are generally used to. The photographs present the faces of children with empty look in their eyes, thus warning about the gravity of the global social issue brought about by uncontrolled use of television.

The attention is additionally captured by using the following slogans: MIND TV; SEE TV; WATCH (OUT) TV; THINK TV; ATTENTION TV; COMMUNICATE TV; TALK TV; FEEL TV [see fig. 3.1.2.3.4.5.6.7.8.9.10.].

The red color was used to symbolize warning. One immediately reacts to the color of red as it is the most aggressive and most dynamic of all the colors, which is also noted by M. Bronzić: "Red color is the most temperamental color which arouses the most intense emotions and speeds up 
heart rate and breathing. In design and art, it is used sparingly as an accent color, in order to emphasize something or make special impression.” (Bronzić, 2012, http://www.bronzic.com).

\section{Guerilla Marketing Exhibition Principle}

Open public space like streets, parks or promenades more and more often become public galleries where lots of people gather as they are easily accessible. [see fig. 2.1.2.].The $21^{\text {st }}$ century brings about some radical changes to the presentation of visual art so that we can more frequently see exhibitions organized in out-of-gallery space. Technological and technical inventions enable arts to be presented in modern ways. The aim of the new, alternative exhibition space is to have information transmitted to consumers as fast as possible and to attract their attention through being a 'novelty'. The impact of outdoor advertising campaigns is directly connected to the presentation of art in out-of-gallery space. (Petenji Arbutina\&Kovačević Vorgučin, 2011, http://proceedings.informingscience.org, p.413-425)

In this project, we use the visual elements of advertising and exhibition principles of outdoor Guerilla marketing. "Art makes use of advertising exhibition principles, while pure art as a basic idea that sells the product is ever-increasingly present in the production of advertising." (see Petenji Arbutina\& Kovačević Vorgučin , 2011, http://proceedings.informingscience.org, p.413-425)

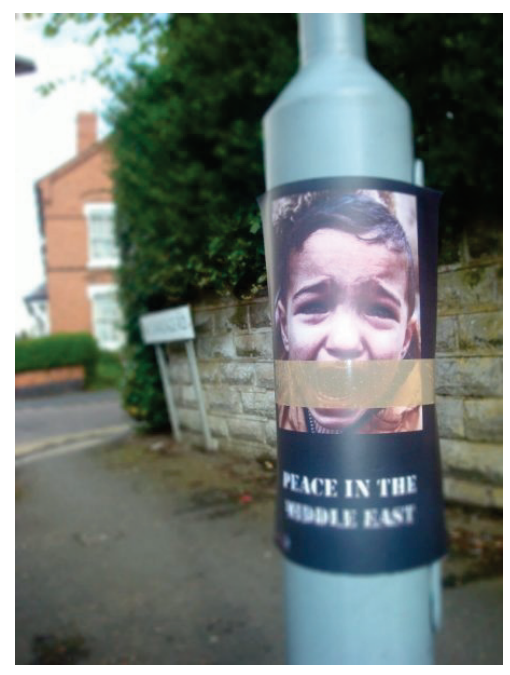

Fig.2.1.

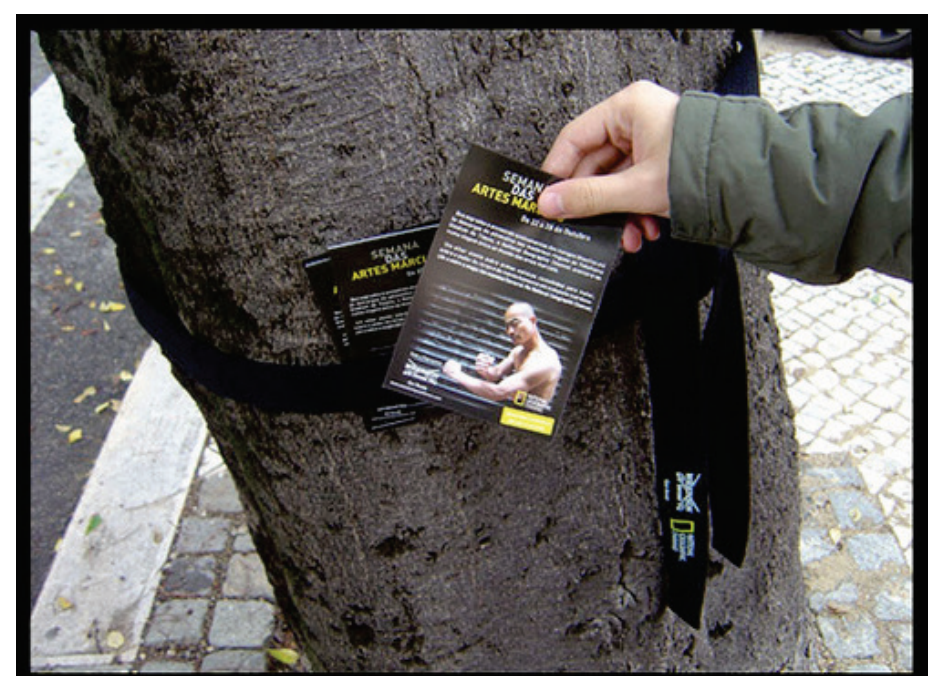

Fig.2.2.

Fig. 2.1. Guerilla marketing campaign to save Gaza

Source: http://www.behance.net/gallery/Save-Gaza-Guerilla-MarketingCampaign/5367501

Fig. 2.2. National Geographic Channel, Martial Arts, guerilla Advertising Source: http://flickrhivemind.net/User/Marketing\%20Post/Interesting

The photographs are printed in the form of stickers whose approximate size is $10 \mathrm{x} 10 \mathrm{~cm}$. They are exhibited at busy places, especially those much frequented by parents/legal guardians and their children (in the vicinity of nurseries, schools, sports centers, city center, bus stops etc.) ...). [see fig. 3.1.2.3.4.5.6.7.8.9.10.]. 

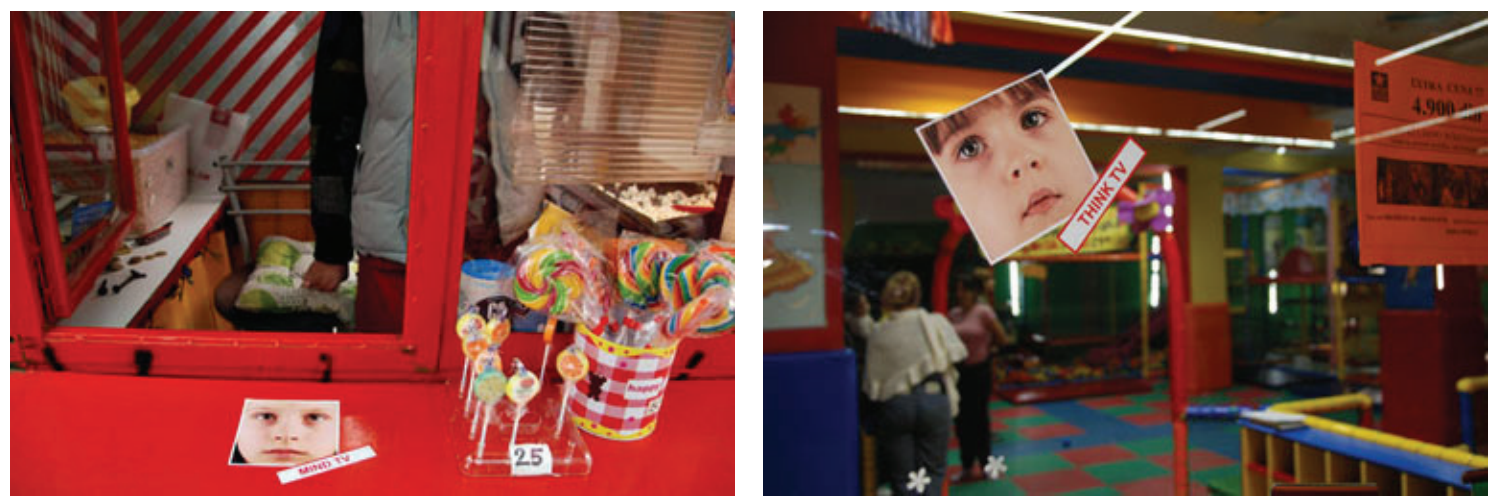

Fig.3.1.

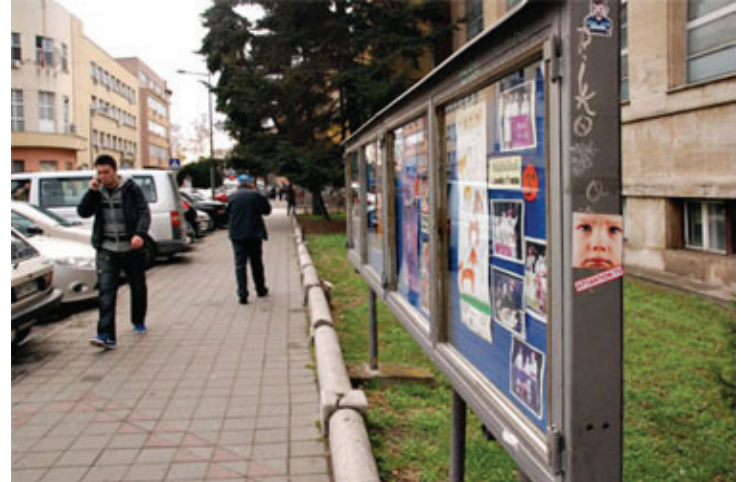

Fig.3.3.

Fig.3.2.
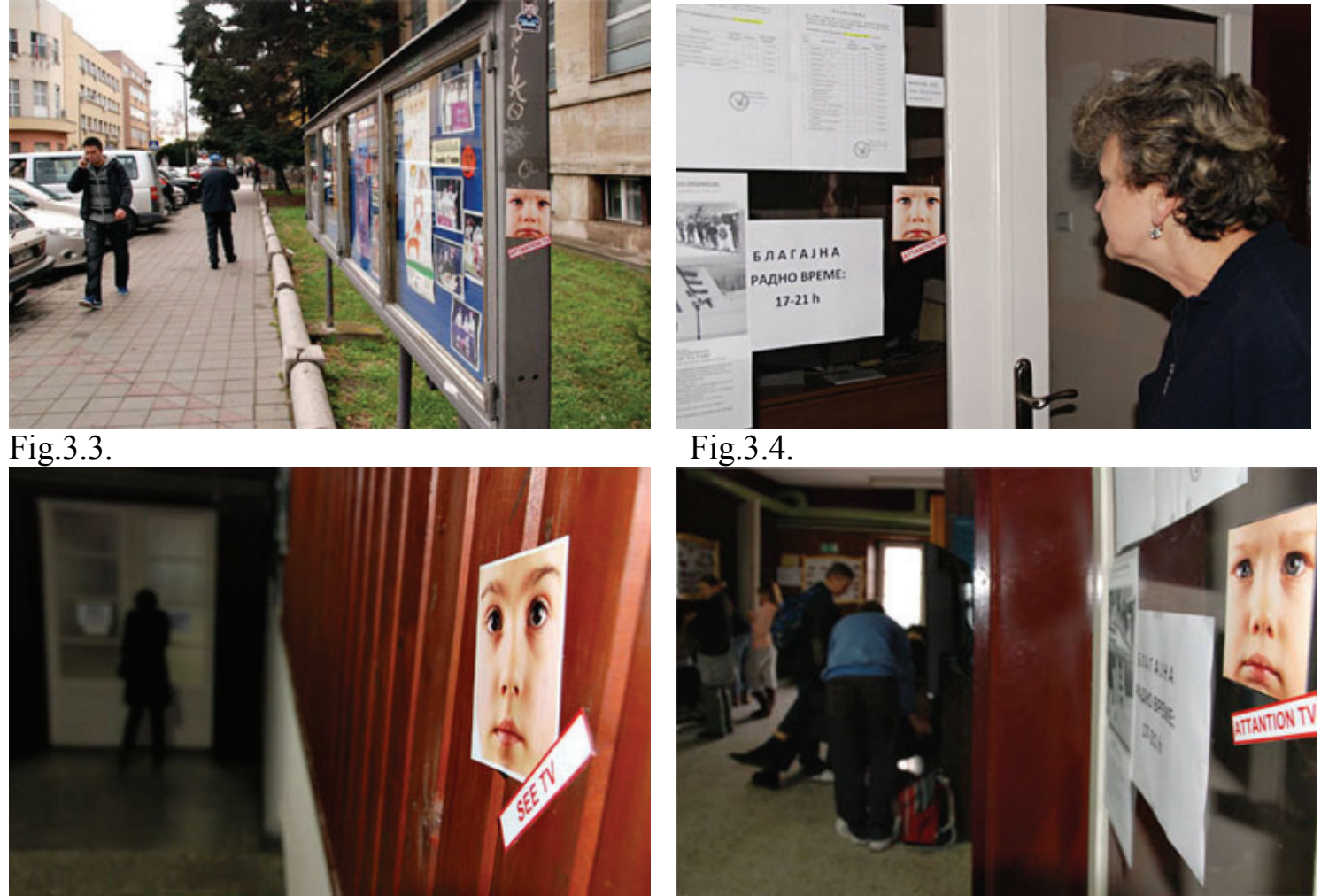

Fig.3.5.
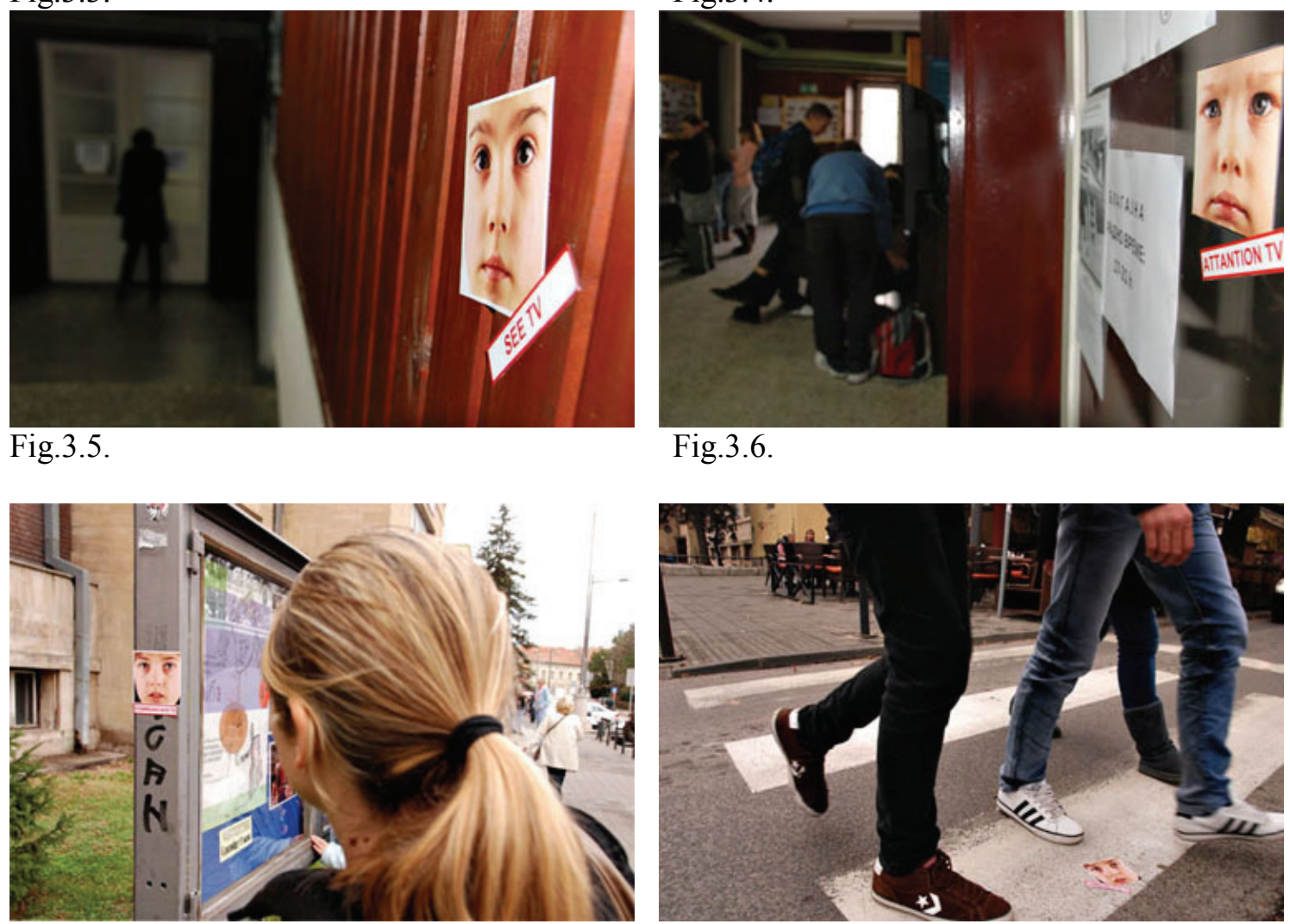

Fig.3.7.

Fig.3.6.

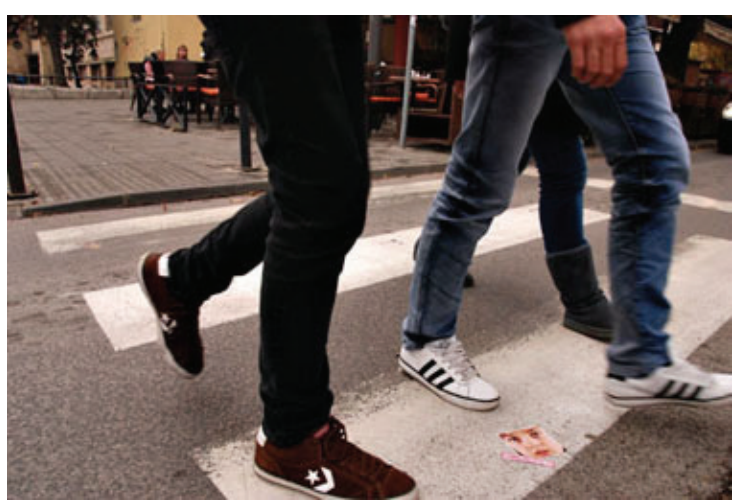

Fig.3.8. 


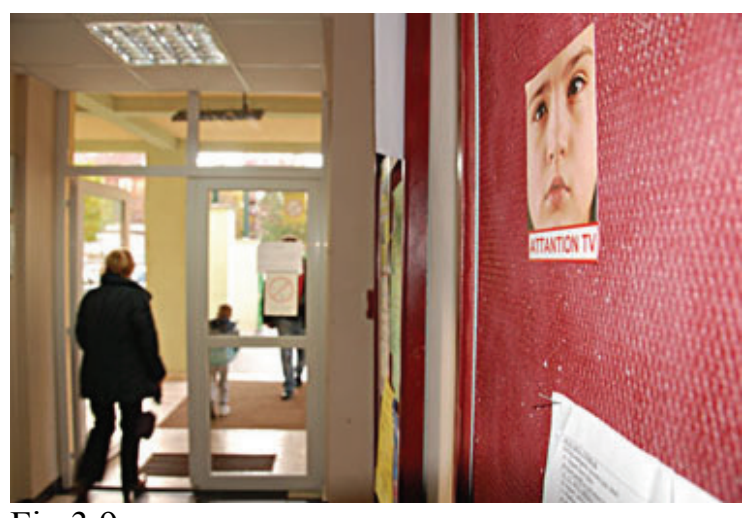

Fig.3.9.

Fig. 3.

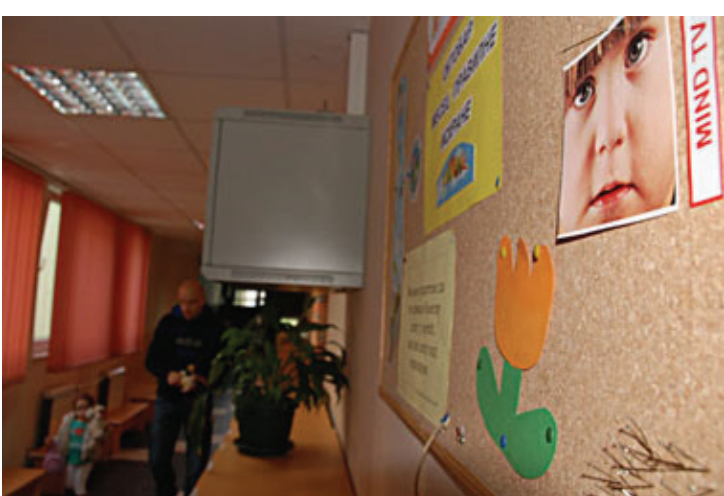

Fig.3.10.

\subsection{6.7.8.9. Mind TV project exhibition}

Personal work by authors, Novi Sad, Serbia

The concept of Guerilla marketing is to have intelligent and creative ideas presented in unexpected places in an unexpected form. Typically, guerrilla marketing campaigns are unexpected and unconventional, potentially interactive, and consumers are targeted in unexpected places. In order to have the message successfully conveyed, we have to ensure that the information on the outdoor advertisement could be read in only two to five seconds, considering that "ninety five percent of the time, either the message or the audience is in motion" (Bruneau, 2011, http://www.marketingscoop.com). In view of that, the elements comprising the advertisement have to be properly organized: the textual message has to be concise, i.e. to contain the maximum of 7 words and to use a distinct typographic solution. Several words, simple background, conspicuous colors and limited use of illustrations or photographs are characteristics of a good advertisement which add up to the immediacy of a visual expression.

When putting on the exhibition, we apply the principle of quantity. This means that a large number of stickers are distributed in order to have them seen by the largest possible number of people who would react to them. The audience has to notice such an exhibition, and thus it becomes the active participant in the visual expression. "It's message work on the advertising principle of 'frequency.' Since most messages stay in the same place for a period of a month or more, people who drive by or walk past see the same message a number of times." (Bruneau, 2011, http://www.marketingscoop.com)

The authors kept a record of people's reactions obtained at several exhibition venues. The results showed that $75 \%$ of people noticed and stopped to view them.

\section{Conclusion}

The viewing of television should be considered not only as a phenomenon by itself, but also in relation to the wider social and cultural environment. The structure of a local community affects both the number of hours spent watching television and the interpretation of the message conveyed by this medium.

The mass media are often more important educational institutions than schools, because they surpass schools in terms of audience size, time and interest dedicated to their audience as well as a wide variety of the content offered. Therefore, we can conclude that the influence of television as a mass medium might be even equal to the influence of educational institutions.

Television is a sort of window on the world, which fosters understanding and friendly relations with other regions and cultures. At any rate, it provides openness, which should be important for regions that (under)developed in turbulent circumstances. 
It is not feasible to force some radical changes or ban television on the grounds that it represents one of the means of manipulation (it has the greatest manipulative power). Therefore, it has to be approached reasonably and transformed into a "healthy use" to the largest possible extent.

Discussions and debates opened by television program, acquired knowledge and a shift in thinking should be the matter of sociological literacy, and should even contribute to further development of family members' intimacy and more effective communication. We have to bear in mind that the sense of intimacy among family members can be heightened by watching particular programs together.

Society, as a whole, has to be stimulated to develop liberal thinking in an individual and to increase the social and cultural standards.

Since art and the art of advertising have become closely intertwined in the post-modern age, we come to a conclusion that the same exhibition principles can apply both to art and advertising. Except for a good idea and an atypical format, consumer's attention should be also attracted by an unusual place where the advertisement is placed. Visual expression is always conditioned by the problem it tries to resolve. Therefore, the concept of visual expression has to draw on social and psychological research apart from the underlying aesthetic and fine arts principles as it relates to entire society.

We consider that the success of the project can be positively evaluated since we made people stop and, at least for a while, notice and react to a visual message, which was the primary aim of the project. It is difficult to evaluate the results of the campaign precisely because it is intended to last about 12 months and to include the repeated distribution of stickers. The final results will be received in 2014 when the survey of parents, pre-school and school teachers is conducted.

Thereby, the authors have proven that art does not merely evoke positive emotions, the sense of beautiful, but that it has its purpose. Through visual media, it educates people and keeps reminding them of important world issues in order to resolve them.

\section{References}

Bronzić, M. (2012). Psihologija boja, [Psychology of color], Retrieved, November, 2012 from http://www.bronzic.com/psihologija-boja

Brown, M. R. (2002). Picturing children: Constructions of childhood between Rousseau and Freud. United Kingdome: Ashgate Pub Ltd.

Bruneau, E. (2011). Outdoor advertising advantages. Retrieved October 2012, from http://www.marketingscoop.com/outdoor-advertising-advantage.htm

Djordjevic, J. (2009). Postkultura [Postculture], Beograd: Clio.

Dragičević Šešić, M., \& Stojković, B. (2007). Kultura: Memadžment, animacija, marketing [Culture: Management, animation, marketing] ( $5^{\text {th }}$ ad.). Beograd: Clio.

Giddens, E. (2005). Sociologija [Sociology]. Beograd: Ekonomski fakultet Univerziteta.

Golubović, Z., Jarić I (2010) Kultura i preobražaj Srbije, vrednosna usmerenja građana u promenama posle 2000.godine [Culture and transformation of Serbia - Value orientations of the citizens during the changes after 2000]. Beograd: Res publika, Službeni glasnik

Guerrilla marketing. (2012). Retrieved January 2013, from http://en.wikipedia.org/wiki/Guerrilla marketing

Higonnet, A. (1998). Pictures of innocence. The history and crisis of ideal childhood. London: Thames and Hudson Ltd. 
Krilić, A. (2010, November). Djeca i mediji III - Djeca i televizija [Children and media III - Children and television]. Retrieved November 2012, from http://roditeljstvo.com/vijesti/djeca-i-mediji-iii-djeca-itelevizija

Tanjug. (2010). Kultura u Srbiji je na poražavajućem nivou. [Demoralizing level of culture in Serbia]. (2010, Septembar). Retrieved October 2012 from http://www.b92.net/kultura/vesti.php?nav_category=272\&yyyy=2010\&mm=09\&dd=14\&nav id=4586 $\underline{60}$

Lemish, D. (2008). Deca i televizija [Children and television]. Beograd: Clio.

Lester, P. M. (2006). Visual communication: Images with messages (4th ed.), USA: Thomson Wadsworth.

Levinson, J. C. (2007). Startup guide to Guerrilla marketing: a simple battle plan for first-time marketeers. USA: Entrepreneur Media Inc.

Levinson, J. C., \& Godin, S. (1994). The Guerrilla marketing handbook. USA: Mariner Books.

Lippman, W. (2007). Public opinion. USA: NuVision Publications, LLC.

Office of the Chief Information Officer. (2012). 7 things you should know about visual information. The Ohio State University. Retrived March, 2013, from http://ocio.osu.edu/elearning/toolbox/brief/visualinformation/7-things-you-should-know-about-visual-information

Petenji Arbutina, S., \& Kovačević Vorgučin J. (2011). (Non)Art in the Art of Advertising. Proceedings of Informing Science \& IT Education Conference (InSITE) 2011. Retrieved from http://proceedings.informingscience.org/InSITE2011/InSITE11p413-425Petenji325.pdf

Potter, J. (2011). Medijska pismenost [Media literacy], Beograd: Clio.

Republički zavod za statistiku Srbije [Republic Statistical Office of Serbia] (2012). Retrieved from http://webrzs.stat.gov.rs

Simpson, B. (2004). Children and television. New York: Continuum International Publishing Group, Limited.

Tanjug, Istraživanje o kulturnim navikama građana Srbije, Srbe kultura ne zanima [Research on the cultural habits of citizens of Serbia, Serbs not interested in culture]. Retrieved September, 2010, from http://www.blic.rs/Kultura/Vesti/207125/Srbe-kultura-ne-zanima

Stanković, M. (2012) Deca i TV [Children and TV] Retrieved September, 2012, from http://www.stetoskop.info/Deca-i-TV-331-c5-content.htm

Vujčić Popović, D. (2010). Uticaj televizije na decu [Television impact on children]. Retrieved October, 2012, from http://www.vrticiportal.com/roditeljstvo-i-vaspitanje/dete-i-televizija-stetan-uticajtelevizije-na-decu.html 


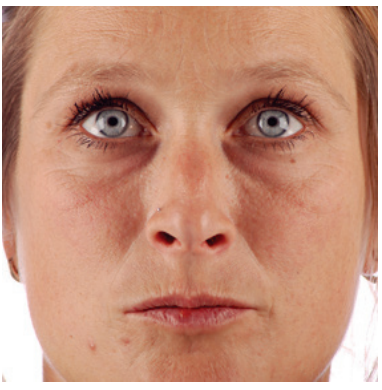

\section{Biographies}

Sibila Petenji Arbutina, born 1976, is a lecturer at the Higher Technical School of Professional Education, Novi Sad, Serbia. She teaches photography courses: Applied Photography course and Theory and Visual Elements of photography. She holds a MS in Graphic Art at Academy of Art, Novi Sad. She had 11 solo and many group exhibition. Her professional fields of interests are photography, graphics, painting, and multimedia art.

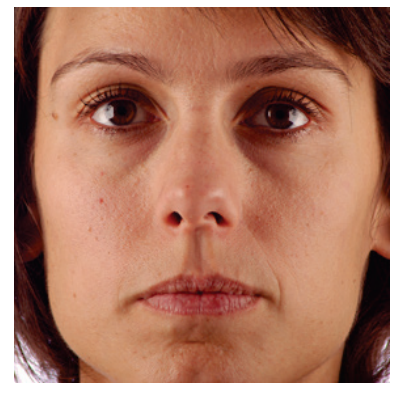

Jelena Kovačević Vorgučin, born 1975, is an assistant professor at Academy of Arts in Novi Sad, and lecturer at the Higher Technical School of Professional Education, Novi Sad, Serbia. She teaches photography courses: History and Aesthetic of Photography and Documentary Photography. She holds a MS in Photography at Faculty of Applied Arts in Belgrade. She had 8 solo and many group exhibition. Her professional fields of interests are photography, advertizing, design, and multimedia art. 